\title{
THE ORIGIN OF THE ENGLISH COURTS OF COMMON LAW
}

\author{
George Burton Adans \\ Yale University
}

It has seemed to all scholars necessary to regard the event recorded of the year II 78 by a contemporary chronicler as the beginning of a new epoch in the history of English judicial institutions. The chronicler says that King Henry II, after an investigation of the matter,

"when he learned that the land and the men of the land were burdened by so great a number of justices, for there were eighteen, chose with the counsel of the wise men of his kingdom five only, two clerks and three laymen, all of his private family [household], and decreed that these five should hear all complaints of the kingdom and should do right [declare right in each case] and should not depart from the king's court but should remain there to hear the complaints of men, with this understanding that, if there should come up among them any question which could not be brought to a conclusion by them, it should be presented to a royal hearing and be determined by the king and the wiser men of the kingdom."

It is impossible to interpret this account otherwise than as the establishment in the judicial organization of the kingdom of a new court, of a court which in that form did not exist before, and it has been universally so interpreted. The opinion about it which prevailed until a generation ago may best be outlined from the account in Stubbs's Constitutional History of England. ${ }^{3}$ He held, in agreement with the view then regarded as settled, that it was the court of King's Bench which was established in II78 "as a separate committee of the Curia "Regis," holding sessions in banco in the Curia Regis "nominally but "not actually coram rege." The court of Common Pleas as a distinct

\footnotetext{
${ }^{1}$ Much has still to be done with regard to the personnel of the new court but it seems fairly certain that the limitation to five justices was not permanent.

${ }^{2}$ Itaque dominus rex moram faciens in Anglia quaesivit de Justitiis quos in Anglia constituerat, si bene et modeste tractaverunt homines regni; et cum didicisset quod terra et homines terrae nimis gravati essent ex tanta Justitiarum multitudine, quia octodecim erant numero, per consilium sapiertium. regni sui quinque tantum elegit, duos scilicet clericos et tres laicos, et erant omnes de privata familia sua. Et statuit quod illi quinque audirent omnes clamores regni, et rectum facerent, et quod a curia regis non recederent, sed ibi ad audiendum clamores hominum remanerent; ita ut si aliqua quaestio inter eos veniret, quae per eos ad finem duci non posset, auditui regio praesentaretur, et sicut ei et sapientoribus regni placeret terminaretur. I Gesta Regis Henrici Secundi (Rolls Series) 207; Stubbs, Select Charters (9th ed. I9i3) I55.

secs. I45, I63, and 233. No change was made in the edition of Vol. I which was published in 1897 .
} 
court owed its existence to c. I7 of Magna Carta by which the common pleas were "separated from the other pleas which came before this "court," and at the beginning of the reign of Henry III the three common law courts were in existence with practically the same distinctions in jurisdiction as those which were finally considered to separate them in theory.

No departure was made from this interpretation until the appearance of the first volume published by the Selden Society, Select Pleas of the Crown, in 1888 . In the introduction to that volume 4 Professor Maitland made two decided modifications of the older explanation. He was of the opinion that the new court established in II78 was the ater court of Common Pleas, ${ }^{5}$ still as a differentiation from the earlier zuria regis; and he held that in this court there appeared after a time and by gradual degrees a split, or secondary differentiation; by which in the end the court of King's Bench was formed. That is, the new court contained in itself, as yet undifferentiated, both the later courts, and it was by the natural development resulting from its use that, a generation or two later, probably in the reign of John, it began to separate into the two courts of Common Pleas and King's Bench, the latter thus not a direct differentiation from the small curia regis or Council but a division formed in the new court of justices and not as yet known technically as King's Bench but only as coram rege. The division between the two, however, was not as yet sharply made. In I893 Maitland carried farther the history of these courts with especial reference to the judicial organization at the end of the thirteenth century. ${ }^{8}$ In 1894 Mr. L. O. Pike in his Constitutional History of the House of Lords elaborated this explanation of what was done in $1178,{ }^{7}$ without making reference to Maitland's discussion but with considerable new evidence, and since that date it may be regarded as the current explanation. ${ }^{8}$ Pollock and Maitland's History of English Law which appeared in 1895 adds nothing to the conclusions already reached.

\footnotetext{
- Pp. xi-xvii; cf. I Maitland, Bracton's Note Book (1887) 56-58.

The name, court of Common Pleas, was not used until some generations after the founding of the court. Glanvill, who was already a royal justice in II78 and chief justiciar in II80, speaks of it in common with other courts as curia regis (I. 3,5$)$, often apparently not thinking it necessary to be exact or to distinguish between different courts. It is referred to frequently in the writs in his book as coram justiciis meis apud Westmonasterium, or coram, justiciis in banco sedentibus (II. 6), or residentibus (VIII. I; XI. I). The official title of the justices was "the justices of our Lord the King of the Bench." In this article the court is referred to as the court of Common Pleas, the central court'at Westminster, the Common Bench; and the Bench.

- Maitland, Memoranda de Parliamento (Rolls Series) Ixxix-lxxxv.

Pp. 33-43.

- See I Holdsworth, History of English Law (Ist ed.) 34; Poole, The Exchequer in the Twelfth Century (1912) I80, I82; McKechnie, Magna,Carta (2d ed. I914) 263 .
} 
In a note to Chapter. III of my. Origin of the English Constitution of IgI2 entitled "The Origin of the Court of Common Pleas," it was tentatively suggested that a further considerable modification of the current explanation should possibly be made. It was said that if the account of the chronicler quoted above be interpreted as record evidence would be, it would imply that the new court was not a natural differentiation from the existing curia regis, or Council, like the Exchequer court, but was created all at once by an art of legislation as a result of the experience which had been gaired in working the itinerant justice system. The new royal prerogative procedure, the procedure of writs and juries, which it had been one especial function of the itinerant justices to render accessible to litigants generally, had proved popular, and apparently there had arisen a demand that it should be at all times obtainable and not be at the service of the public only when the special royal commissioners were going their circuits through the counties. $^{10}$ The new court was a permanent itinerant justice court, held at a central point, in session between the iters of the justices and accessible to anyone from any part of the kingdom, if he obtained the necessary permission, that is, the necessary writ. It was also said that, if this explanation is correct, the court established in $I I 78$ did not divide into two by a later differentiation, but that the court of King's Bench was formed some time afterwards by a normal differen-

\footnotetext{
Pp. I36-I43. This explanation of the origin of the court of Common Pleas was accepted by Professor James $\dot{F}$. Baldwin, together with a further outline of the general differentiation of the curia regis during the period covered by the present article, and was developed in the early chapters of his The King's Council (1913). See p. 47, n. 3 of that work.

${ }^{10}$ If we may trust the evidence of the pipe rolls in their listing of judicial amercements under the various courts which made them, almost the only records of the time which may be called judicial, then no change in actual practice was made by the legislation of II78. The pipe roll headings are the same after as before that date. These rolls do, however, suggest an explanation of what took place which is at least worth consideration. The placita ad Scaccarium and part at least of the placita curie seem to imply that the itinerant justices after their return from their iters still continued to sit at Westminster, continuing or completing their unfinished business. 'See for example, 26 Pipe Roll Society (II76-II77) $7,14,28,39,45,62,130,131$, and all volumes immediately before and after II78. The business under these headings is plainly itinerant justice court business. If this explanation is correct, and it can only be suggested forstudy, each group of itinerant justices after returning from its iter sat as a bench for a time doing the same kind of business, new or continued. There would thus be as many central courts as there had been circuits formed. Possibly this may explain the complaint of the number of justices and indicate that the legislation of II78 was a recognition of the necessity of this practice in some form and an attempt to regulate it by combining all continued itinerant justice business in one comparatively small central court before a single bench. There is, I think, both in and out of the pipe rolls, especially in the "fines," evidence to show that it was some time before the new court settled into distinct and definite form.
} 
tiation from the small curia regis or Council. Since this explanation was published, further study of the material tends only to confirm the view then expressed, which is here repeated with more full evidence not as a tentative suggestion, but as an explanation which it is believed will stand the test of investigation.

If this explanation is correct, it should be evident in the facts that the new central court, which becomes in time the court of Common Pleas, was never at any time regarded as the small curia regis, or Council. It should never be found performing the general functions of the Council. It was not the Council, nor an offshoot or committee of the Council; it was the creature of the Council and this seems to be what the facts imply, though the facts which bear on the question are not so numerous as we could wish. ${ }^{11}$ The jurisdiction of the court was a delegated jurisdiction strictly limited by the purposes for which the court was created. ${ }^{12}$ Its jurisdiction was indeed less wide than that of the itinerant justices, though it was in one sense a permanent session of their court. The new central court performed no administrative function; it developed no equity jurisdiction, a fact which is decidedly significant and would seem an impossible limitation of any court which was a real differentiation from the Council, instead of a legislative creation, at least before the middle or last part of the thirteenth century, that is, before the distinction between equity and common law began to be consciously made. The itinerant justice court carried the Council into the counties, not as by itself Council, but under a commission which conferred that authority and which limited the range of Council action, but was intentionally wide enough to serve other needs of government than merely the rendering of justice. On the other hand the permanent itinerant justice court at Westminster was plainly intended to confine itself to judicial businessthe clamores of the people. ${ }^{13}$ And it did do so. Even king's pleas as tried by the new procedure, the procedure of the Assize of Clarendon, which it was a special function of the itinerant justice courts to try, do not appear on its rolls, though it is hard to say theoretically why they

\footnotetext{
"The historian may sometimes perhaps feel sure enough of the general principles which he believes to be controlling the development which he is studying to predict, as some astronomers have done, though probably not with quite the same confident assurance, that the facts which are still to be uncovered by future investigators will confirm the conclusions which he has reached.

2 Habet etiam curiam et justitiarios in banco residentes, qui cognoscunt de omnibus placitis de quibus authoritatem habent cognoscendi, et sine warranto jurisdictionem non habent nec coertionem. Bracton, f. I05b. See also ff. I08, ro8b.

${ }^{3}$ Clamor is a word of more frequent use in Normandy than in England and was there used of criminal appeals or complaints. 2 Tardif, Coutumiers de Normandie, Index. I know of no reason why it should not be so used, since appeals were in the same way as civil cases suits of one individual against another, but such a use in England was certainly rare.
} 
should not. Also criminal appeals, which strictly are clamores, that is, are civil suits on the complaint of individuals, are rather uncommon, and seem in some cases at least to involve points of difficulty which may account for their appearance in the court. Nearly all the business of the court is the trial of civil suits and nearly though not quite always by the new procedure. ${ }^{14}$

The fact that the central court at Westminster is not the Council, nor any differentiation from the Council, is still more strikingly seen in two facts that appear in the judicial history of the thirteenth and fourteenth centuries. One is the treatment of its errors. In the original legislation which established the court, it was provided that questions of difficulty arising in the court should be referred to the king and the Council for their decision. ${ }^{15}$ This was nothing more than the natural rule for an institution of delegated jurisdiction. ' Its formal expression, however, undoubtedly made more easy, what was also in a short time evidently felt to be a natural inference, that the Council should assume the power, or more correctly exercise the power (for it would belong to the Council normally) of correcting errors which it made, to which attention might be called by the complaint of the parties affected. This right, manifestly a right of superior jurisdiction as exercised by the court from which the authority of the lower court was derived, was firmly established in the course of the thirteenth century, was indeed never questioned, and was continued in natural course in the court of King's Bench.

Equally striking is the distinction set up between the courts in the operation of the principle which had been emphasized by Magna Carta c. 2I that barons should be amerced by their peers only. Pike and Vernon Harcourt have shown clearly that this principle was interpreted to exclude the itinerant justice court from the right of amercement

\footnotetext{
${ }^{24}$ On the mixture of procedure in the courts of this time see Adams, Trial by Peers Again (IgIg) 28 Yale LaW Journat, $46 \mathrm{I}$. Cases of old procedure alone or of mixed new and old are: I4 Pipe Roll Soc. 2I-22; 24 id. 24024I; 2 Palgrave, Rotuli Curiae Regis, 4I, 5I, 58; Placitorum Abbreviatio, 38, $59 \mathrm{~b}, 68 \mathrm{~b}$; Bracton's Note Book, Nos. 390,396 . An appeal is always presumably a case of the old procedure, and many are so tried throughout, but in some a jury is asked for and granted, showing that no inconsistency or hesitation was felt in passing from one to the other. I Selden Soc., No. ro4; 2 Palgrave, op. cit., 30-31, 244. While Glanvill is pre-eminently a book of the new procedure, the considerable place which the old procedure takes in it should not be overlooked. More significant than the essoin from our point of view is the discussion of the duel (II. 3) and the cases in which per verba placitabitur et terminabitur (II. 6; III. I; IV. 6; VI. 8).

${ }^{25} \mathrm{It}$ is hardly possible to regard the distinction between sapientes and sapientiores in the chronicler's account of the legislation of 1178 as otherwise than intended. Per consilium sapientium regni sui unquestionably means the great Council. Sapientiores means a smaller, selected body. In practice the reference was to the Council. See the instructions to the justices of 1218, I Rotuli Litterarum Clausarum, 383; I Madox, Exchequer (I769) 529, 0.
} 
and, by inference at least, the central court at Westminster also. ${ }^{16}$ Certainly the argument from silence would seem to be here of valid force, for in all the judicial material of the thirteenth century no evidence has yet been discovered to show that in looking for a court to "afeer" the amercements of barons any effort was made to use the central court. The argument from silence becomes morally conclusive when we add to the silence of the records Bracton's positive statement of the courts that may afeer-Exchequer and Council only, Exchequer still exercising the functions of the Council and coram rege, the later King's Bench, not yet sufficiently differentiated from the Council to be thought of as a separate court in this connection. Thus the judicial development of the thirteenth century draws a clear line of distinction between coram rege and Exchequer on one side, as continuing functions of the Council because they are natural outgrowths of it, and the court of Common Pleas on the other as inheriting no Council functions, because it was not an outgrowth but a creature of the Council.

In sharp contrast with the relationship which the facts of thirteenth century judicial history show between the Council and the Exchequer on one side and the court of Common Pleas on the other, is the relationship which they show between the latter and the itinerant justice courts. Here the relationship is clearly one of practical identity. Each treats the other as if it were itself. All through the early history of these courts, down certainly to the end of the minority of Henry III, cases begun in one are freely transferred to the other, not for retrial or review but to complete the trial; and this is done, so far as the records show, by the simple act of the justices without writ or mandate of any higher authority. ${ }^{18}$ By this I do not mean merely the assignment of a day for trial in another court. That is a process which

\footnotetext{
${ }^{18}$ Pike, House of Lords (I894) $255 \mathrm{ff}$; L. W. Vernon Harcourt, His Grace the Steward and the Trial of Peers (1907) 289 ff., and (I907) 22 ENG. HIST. Rev. $733 \mathrm{ff}$. Pike shows the practice to have been older than the Great Charter. See McKechnie, Magna Carta, 295 ff. The objection was not that individual justices were not the peers of barons (Pike, op. cit., 255), but that the courts which they formed were not courts of peers because they were not forms of the Council. The same justices in the Exchequer or the Council were the peers of barons because they were then members of the Council. The barons never had any objection to the trial of their civil cases in the new courts and appear constantly on the rolls as plaintiffs as well as defendants.

${ }^{17}$ Comites vero vel barones non sunt amerciandi nisi per pares suos et secundum modum delicti, et hoc per barones de scaccario vel coram ipso rege. Bracton, f. II6b.

${ }^{28}$ The writ pone was apparently sometimes used by one of the parties in a case, not by the court, to transfer the case from a county court meeting before the itinerant justices to the Bench, never vice versa, but the instances in which the court is clearly that of the itinerant justices and not the king's county court before the sheriff are rare. See Bracton's $N$. B., No. 92. It was used in the same way to bring a case from the sheriff's county court into the itinerant justice court. II Somerset Record Society, No. 730; Bracton's N. B., No. I776.
} 
assumes no identity between the courts concerned. I refer rather for example to the numerous cases in which, the trial being held in one or the other of these two courts, a day is assigned the parties to hear their judgment in the other. The trial is held in one court and the judgment on that trial is rendered in the other, as if the two courts were really one. ${ }^{19}$ The rolls give us other cases in which assizes or trials of other forms begun in one court and carried only partly to judgment are finished in the other. That in most of these cases the trial goes from the itinerant justice to the central court, is not material because that would be natural and almost necessary, since a future iter of the justices would be of uncertain date, while the parties could always be assigned a day at the central court as holding regular terms. $^{20}$ There is no evidence in these assignments that the central court was regarded as a superior court. There are one or two cases in which the central court does indeed correct the errors of the itinerant justices, ${ }^{21}$ but not even then as a court of superior jurisdiction as that phrase is commonly interpreted, but rather as a court of the justices united in a full bench, on the principle of the later court of Exchequer Chamber. ${ }^{22}$

The identity of these two courts is indicated even more obviously by the nisi prius relationship which seems to have existed from the

${ }^{19}$ The earliest court roll which has been preserved to us is a roll of the Bench for the Trinity term of II94. It has been edited by Maitland in Three Rolls of the King's Court, 14 Pipe Roll-Soc., I-59. So clear does this record make it that the Bench treats sessions of the itinerant justices, which are evidently about to be held throughout the country, as if they were sessions of itself, making adjournments and assignments to them as it would to subsequent sessions of the Bench, that the evidence of identity is equivalent to demonstration. This iter took place in September, II94 (3 Hoveden, 262; Stubbs, Select Charters, 215), and the evidence in the roll that it is about to occur may be added to the proofs 2ssembled by Maitland that it should be dated in that year. See adjournments by the Bench to hear judgment in the itinerant justice court, pp. 6 (two cases), $13,14,29,47,52$ (two cases); assizes and other cases to be finished, pp. 2, 4, 5, 7, II (two cases), I3, I7, 38, several in essoins 5I-58. Further exampl:s may be found throughout the period. See Bracton, f. 368: Et eodem modo excusat consimile auditorium vel aequale, ut si justiciarii de banco suo nomine scripserint justiciariis itinerantibus, vel e contrario; licet par in parem non habeat imperium.

${ }^{20}$ That this could not always be done with certainty even in case of the Bench is shown by the practice of giving days at the Tower of London, especially when a distant day is set as in some essoins. Bracton gives as the reason for giving days at the Tower quia justiciarii non semper continue per annum in banco sunt residentes, f. $353 \mathrm{~b}$. As examples of days set at the Tower, see 14 Pipe Roll Soc., 22, 52: I Palgrave, Rotuli C. R., 400 : II Som. Rec. Soc., No. I376.

${ }^{21}$ The court of review formed in I219 as recorded in plea 67 of Bracton's $N . B$ is very like the later Exchequer Chamber. Instances of the Bench acting as a court of errors are: $i d$. Nos. $243,530,564,1445$. The last only concerns the itinerant justices. On the limitations of the court in this respect and in others which find their explanation in its origin, see 1 Holdsworth, op. cit., at pp. 77-78.

" I Holdsworth, op. cit., rog. 
beginning, or at least from a very early date, and which is probably implied in c. 2 of the itinerant justice commission of II94. ${ }^{23}$ The cases on the calendar of the central court not yet reached for trial when the justices go into the counties are transferred there to be tried by them. That is, a trial of the case before the itinerant justices is the same as a trial before the Bench. The nisi prius reservation had become common form in the assignment of days in the Bench as early as I200, and it appears in plain terms in the writ for the iter of I218. Of course it is not implied that jurisdiction at nisi prius or the nisi prius clause in the writs of summons had yet been worked out as they came to be by the end of the century, ${ }^{24}$ but only that here was the foundation on which the later development rested, existing from the beginning: in the relationship of the two courts. This identification of the two courts came to be expressed most completely in the entire suppression of the jurisdiction of the Bench for the county in which the justices of the eyre were holding their court. ${ }^{25}$ That the two courts are one could hardly be more clearly assumed.

It may be added that the character of the court of Common Pleas as a legislative creation rather than as a natural outgrowth of the Council is reflected in the fact that it undergoes no historical development in organization or jurisdiction or relationships. The procedure which is employed in its business develops greatly and the amount of work which falls to it increases greatly and is shared with other courts, but as itself a court institutionally considered it remains to the end what it was at the beginning. Of the other two common law courts this is not true, but throughout the whole thirteenth century the natural growth within the Council in which they had their origin continues and changes progressively their jurisdiction and relationships.

From the provision in the legislation of $\operatorname{Ir} 78$ requiring the reference of difficult questions to a royal hearing (auditui regio) originated the court of King's Bench. With the rapid expansion of common pleas

\footnotetext{
${ }^{23}$ The justices are to try all pleas summoned before them by writ vel a capitali curia regis coram eis missis. Stubbs, Select Charters, 253. This provision undoubtedly is to be interpreted in the sense of a record of r220: et posita fuerunt coram eis (the itinerant justices) omnia placita in eodem statu quo fuerunt apud Westmonasterium. Bracton's N. B., No. 1412. The capitalis curia regis of the commission of 1194 was as in Glanvill the new central court. Glanvill, XII. 23; cf. the case of Stephen $v$. Robert (II94) I4 Pipe Roll Soc. I6. See the nisi pritus condition fully stated in IIg9: nisi justiciarii interim venerint in partes illos. I Palgrave, Rotuli $C . R$. 453 ; cf. id. 421 , and Bracton f. rro. As common form see 3 Selden Soc, Select Civil Pleas, Nos. 6, 10; 3 Staffordshire Historical Collections, 145 . The practice is clearly defined in the writ to the sheriff for the iter of 1218 , in form as it remains in Bracton. Rot. Litt. Claus. 380; Bracton f. Iog; cf. the writ for , 1231 in Stubbs, Select Charters, 354.

${ }^{36}$ I Holdsworth, op. cit., at p. II7; 4 G. J. Turner, Year Books Edward II., Selden Soc. xxiv; 3 Encyc. Laws of England, 78.

${ }^{25}$ I Pollock and Maitland, History of English Law (2d ed. 1899) .20r; I Eyre of Kent, Selden Soc., xviii, xxxiii.
} 
business after the new procedure came into use, many new and difficult questions arose upon which the justices, itinerant and capitales, ${ }^{28}$ desired the opinion of the highest authority, and the reference provided for was clearly to the highest authority, to the king and the sapientiores, that is, to the Council, ${ }^{27}$ to the authority which had created these courts and their procedure, from which were derived their powers and the regulations under which they acted. The meaning of this reference is to be seen in the form which it takes during the absence of the king from England, when it becomes a reference to the justiciar, coram archiepiscopo, or to the council direct as frequently during the minority of Henry III. ${ }^{28}$

The first effect of the frequency of reference under this provision was upon the phrase coram rege. This phrase had been in common use since the Conquest but in a general and untechnical sense. ${ }^{29}$ In

${ }^{*}$ On the justiciarii capitales as the central court, see note 23 supra. Add to the reference to Glanvill there given, VIII. 5, 4 Bracton's designation of the court is the same as Glanvill's: ut autem de capitalibus justiciariis in banco residentibus ad presens taceamus, f. 108b. In Ir94 a case stopped before the itinerant justices by a charter permitting trial only coram rege vel capitali justiciario goes on in the central court of Common Pleas.

"See note I5 supra.

${ }^{21}$ I Palgrave, Rotuli C. R., 14, 87; 44 Pipe Roll Soc., I4; Bracton's N. B., Nos. 12, 1306; I Rot. Litt. Claus. 383 , as in note 15 supra.

- In earlier times and until some time after the organization of the new court in 1178 , the phrase coram rege was used chiefly in two connections: in reference to an actual trial, and in grants relieving the donee from pleading in any except a royal court. This grant seems to have been desired in order to escape from the local and baronial courts and, unless unusually specific, seems to have been satisfied by a trial in the great or small Council or in a court of any royal commissioner above the rank of sheriff. When the bodily presence of the king is plainly insisted upon, the emphasis indicates the exceptional case. As examples may be cited (in some instances ante regem): (William I) Davis, Regesta, No. 36; id. Appendix, xiv, xvi, cf. No. 183a, and Round, Documents in France (I899) No. I16; Davis, op. cit., No. 63; Haskins, Norman Institutions (I918) 2I-22; I Domesday Book, 58b; coram regina, I Domesday, 48b, 238b. (William II) Davis, op. cit., 429. (Henry I) 2 Chron. Mon. de Abingdon, I64; I Cart. Mon. Gloucestriae, 14, 236; :6 Dugdale, Monasticon, 1043; I Madox, Exchequer, 93, w; I Rymer, Foedera, 12; coram me vel coram proprio justiciario qui super omnes alios vice mea justitiam tenet, II Gallia Christiana, Instr., I56, from Valin, Duc de Normandie (1909) I09, n. 2. (Stephen) 2 Chron. Mon. Abingd., I8r; Chron. Mon. de Bello, 66. These references give all the instances $I$ have noted from the reign of William I, but no attempt has been made to complete later reigns. After the accession of Henry II, and especially after the opening of the royal procedure to the public, cases of this untechnical use become very numerous. I Madox, Exchequer, 116-121; Round, op. cit., Nos. 45, 57, 100, 101, $108,109,129,267,483,574,700,1280,1398$. Some of these are of special interest. See the formulae given in Brunner, Schwurgerichte (1872) 243,409, and nisi in presencia mea' corporali, a Cal. Charter Rolls, 320 . It is, I think, certain that the words coram rege, when standing alone, never meant in any period of their history, early or late, "in the bodily presence of the king." See coram rege in curia sua apud Dublin', Cal. Close Rolls, I227-123I, 344. 
Glanvill, a book written after the legislation of II78, and dealing with almost nothing but the business and procedure of the new courts of delegated jurisdiction, the phrase coram me, that is coram rege, is in constaut use with reference to these courts. ${ }^{30}$ This untechnical use of coram rege, this use of the words even for the Common Pleas court at Westminster, continued at least to the end of John's reign. ${ }^{31}$ It is a survival of the older situation before the increasing development led to the making of distinctions. Meantime there was growing a tendency to regard coram rege as having a limited and therefore a more technical meaning. ${ }^{32}$ This tendency was not merely due to the reference of difficult questions to the Council but it was also a part of the rapidly growing technicality of the whole common law system.

${ }^{20}$ Every writ of summons in Glanvill, except those which constitute the sheriff a justice, is coram me vel justiciis meis, and this is so often explained as apud Westmonasterium that there can be no doubt the reference is to the new central court. In Book VIII the in curia Westmonasterii of c. 3 is plainly the in banco of c. I. There is no evidence in Glanvill that the frequent coram rege referg to anything but the Westminster court. Pike, op. cit. note 16, at p. 37, holds otherwise. In Bracton's time writs summoning. cases before the Bench still used the same form, f. I49. Of course there is no contention that such a writ might not be satisfied by an actual appearance before the king, if the parties could manage it, but the point is that they were satisfied, and were intended to be, by an appearance in the Bench.

"1 Here belongs the familiar case of the abbot of Leicester who was told in 1200 by the court "that all pleas holden by the justices of the Bench were deemed to be holden before the king or his chief justiciar." Maitland, I Selden Soc., xiv, from Plac. Abbr. 32. Cases in which coram rege is satisfied in the Bench are: Plac. Abbr., 67, 69b (two cases), 74, 76, 86b; I Selden Soc., No. II5, a case which concerned the person of the king and in which one party appears actually before the king and the other at Westminster; 2 Palgrave, Rotuli $C . R$., I56, I58, 175-6 (these are along with cases where the distinction seems made, id. I59, I67, 173); Bracton's N. B., No. 243 (I227). 'Days given coram rege to a regular Bench term, of which there are a good many, probably belong here at this date. 3 Staff. Hist. Coll., 69-70, 145.

The abbot of Leicester's case was not the only one in which a special grant was pleaded in bar of a suit in the Bench, though the judgment of the court is not always recorded, Plac. Abbr., $39 \mathrm{~b}$; a day finally given in the Bench, id., $54 \mathrm{~b}$; 2 Palgrave, Rotuli $C . R$., 4I. apparently against the Bench, id. I63, 176. Cases in which the Bench is a second choice in a coram rege process, 3 Selden Soc., No. 40; 2 Palgrave, op. cit. 182; 3 Staff. Hist. Coll. $132 ; 44$ Yorks. Archaeol. Soc., 5. Cases really coram rege by intervention of the king, 2 Palgrave, op. cit., cases really coram rege, 2 Palgrave, op. cit. 95, I73; 3 Staff. Hist Coll., I56. Cases showing discussion by the Council, 3 Selden Soc., No. 190; I Madox, Exchequer, $99 w$; Plac. Abbr., 95, an interesting case. See the cases from John's reign cited in I Madox, Exchequer, 79a ff. All the cases cited in this and the last note are not later than John's reign. except the one noted above. No effort has been made to collect all the cases. Something has been made in this connection of the mention of courts in the judicial fines of the period (I. Selden Soc. xiv), but a comparison of the lists of the justices given in these shows certain difficulties which cannot yet be solved. 
It shows itself in an effort to make the phrase more emphatic and specific. It becomes coram ipso rege, or coram rege ubicumque fuerit in Anglia, ${ }^{33}$ and in general statements we hear of pleas which follow the king. What the use of such phrases indicates is that a distinction is growing in the thought of the time which had not before been noticed and which there is need to express in a new way because the old seems inexact. Coram rege in technical use is coming to mean one distinct thing, and that is the Council acting in its judicial capacity.

This second stage in the development of the court of King's Bench lasted at least until after Bracton had finished his treatise on the law and customs of England. He does indeed in one part of his book show us that he was conscious of the fact that this judicial business of the Council was practically in the hands of a body of justices, who it is highly probable really did all the work. ${ }^{34} \mathrm{He}$ was himself in fact one of these justices. ${ }^{35}$ But he nowhere shows any suspicion that this body in truth constituted a court distinct from the Council. For him the justices in action are the Council. He knows of no court exercising this jurisdiction but the Council. ${ }^{36}$ The same thing is true of Bracton's Note Book, the collection of cases from the judicial rolls which was beyond question that which was made for Bracton's use in writing his treatise. And the same thing is true of the records of the courts, so

"This becomes the technical designation of the King's Bench in summonses; in judgments it called itself "the court of the Lord King now here." (I Selden Soc., xii.) See the declaration of Shareshull, C. J., 27 Edward III., on the three meanings of coram nobis, Bills in Eyre, Selden Soc., xvi.

"Bracton, f. IO5b, and f. IO\&, clearly distinguishes the justiciarios capitales qui proprias causas regis terminant from the justiciariis in banco residentibus, but he does not distinguish the former from the aula regis. Fleta at the end of the century describes the King's Bench accurately enough in a short paragraph (II. 2,5 ) as distinct from the aula regis (II. 2,2 ), but nothing further is said about it, while the aula regis is described at length. Britton uses a few more words but adds nothing to the statement of Fleta (I. I, 4 and II). The evidence that Robert de Brus is to be reckoned the first chief justice of the King's Bench, because he was appointed in 1268 capitalis justiciarius ad placita coram rege tenenda, when compared with the language cited above, hardly seems convincing. The same words would probably be used of any justice of the court, and the date is too early. Fleta says that the king's seneschal in aula sua jam tenet locum capitalis justiciarii regis. I Holdsworth, op. cit., at p. $79 f$.

${ }^{2 s}$ I Bracton's N. B. pp. I8ff.

${ }^{36}$ Both the great law books of our earliest legal history are books of the court of Common Pleas. Glanvill's main theme is that court. It is his capitalis curia (VI. 8). Its justices are his capitales justiciarii. See note 26 supra. The same thing is still in the main true of Bracton. Now and then he lets it appear in a brief passage that he was aware of the existence of a court in closer relation with the king, having justices of its own, and twice he calls them capitales justiciarios (note 34 supra). He nowhere, however, describes this court at length, and he gives no details of its procedure nor of its relation to other courts beyond the single fact of its superior jurisdiction. Elsewhere in many places he calls the justices of the Bench capitales, e.g., f. 108b, $4 \mathrm{IIb}$. 
far at least as these are accessible in print. ${ }^{37}$ There is no evidence down at least to the time of the Barons' War that contemporaries were conscious that a new judicial body, a new court, had been thrown off from the Council.

Meantime another kind of distinction had been growing up which had an influence upon the final differentiation. Magna Carta c. I7 provided that common pleas should not follow the king but should be held in some certain place. ${ }^{38}$ Civil pleas were no longer felt to be, as in Glanvill's time, all of one kind, but communia placita could be distinguished from others which were different, and it was felt that it was not right that they should be compelled to follow the king in his journeyings about the country. ${ }^{30}$ Other pleas, those, it comes very

"Sharp technical distinction between the courts of Common Pleas and coram rege during the whole period, while it was undoubtedly forming, was still not invariably the rule. Though it is difficult from the way in which the records upon the rolls were made up, (uniting as they do in some cases into one record the whole trial of the case in whatever courts held or at whatever dates), to be sure that the whole process as it stands recorded actually took place in the court whose roll we have in hand, there can still be little doubt that the roll fairly represents the business of the court. From the coram rege roll of 1234-5, considered the first of the continuous series, Bracton's Note Book excerpts twenty-seven pleas, Nos. IIO6-II32 incl. Of these, ten, Iro7-15-16-18-20-25-26-28 29-3I, show no clear reason why they should be on this roll. Certainly they could be paralleled by cases of the same period from the rolls of the Common Bench. I think the same thing can be shown of every coram rege roll before 1260 and perhaps later. An interesting roll as showing the character of these records is that extensively drawn upon by the compiler of the Placitorum Abbreviatio, ro6ff. It shows clearly that the roll is not made up of cases coming coram rege in any one place or in any sessional terms or before a court of uniform composition. Compare the court on roga with that on rob. See also the roll of I242-3, id. Ir8-120. I have no doubt that cases technically coram rege began, probably before 1250 , to be decided by a bench of two or three justices in attendance on the king, but $I$ have not found a clear instance of the fact in any record which I have read. I am leaving out of account the question of the use of the new prerogative procedure coram rege, which is too large a subject to enter upon here, but it may be useful to note in regard to. it, as well as to the main subject of this note, that the court of King's Bench, which was by the end of the century a naturally formed offshoot of the Council, was finally recognized as possessing an original jurisdiction in certain matters which had at first belonged to the Common Bench, e.g., criminal appeals, trespass, and others in which the king was thought to have an interest. The appearance of cases which seem to be ordinary common pleas on the coram rege rolls may sometimes be accounted for, even where the fact is not evident in the record, by the king's prerogative right of ordering any case he pleased coram rege or by the original jurisdiction of the Council, with which nothing had as yet interfered.

${ }^{28}$ It is quite possible that this chapter of the Great Charter ought to be regarded less as affecting the central court at Westminster than as putting a limitation upon the original jurisdiction of the Council or upon that of the court coran rege.

${ }^{20}$ While it is probable that the central court sometimes held sessions in other places than Westminster, and while it is certain that common pleas were some- 
quickly to be said, in which the king has a personal interest, those which affect his royal dignity or rights, may properly do so. This was not, as was at one time thought, a new distinction of courts that had already begun in another way. It was a classification of business, but it necessarily involved an assignment of it by classes to the different courts which had already begun to be distinguished. It undoubtedly assisted in that process of distinction, and in one sense it may be said to be the beginning of an original jurisdiction for the later court of King's Bench. It was probably along this line that the criminal jurisdiction of the King's Bench was obtained. ${ }^{40}$ But the very important fact should not be overlooked that the Council, which was the only court coram rege as yet, had a very extensive original jurisdiction entirely independent of and much earlier than this development.11

It is not proposed to follow here this differentiation into the time beyond the age of Bracton when the King's Bench became a distinct court, recognized as an independent institution separate from the Council, ${ }^{42}$ because the final stage of its differentiation is so interwoven with a wider process of the same kind, affecting the whole position of the Council, that far too much space would be required. When the fact becomes clear that the coram rege business of the Council is set-

times tried in other places by some court not of itinerant justices, the practice from the beginning seems to have been general, almost universal, that the Bench sat at Westminster. In Glanvill and in the early rolls and fines it is constantly spoken of as apud Westmonasterium, and the original official designation of it seems to have been "the court of our Lord the King before the justices at Westminster" or "the court of our Lord the King at Westminster."

${ }^{\circ}$ This suggestion as a subject of investigation of considerable importance can here only be indicated. It is certain that there was in the first half of the thirteenth century a growth of the feeling that certain pleas, which in the twelfth century had been common pleas without question, should be more immediately coram rege as affecting the king's person, dignity or interests. These are criminal cases, those involving a charter of the king's or, sometimes at least, a tenant in chief, certain ecclesiastical cases, and trespass. See Glanvill, I, 32, 5 ; Bracton's N. B. Nos., I2, 1220; 3 Staff. Hist. Coll., 124, I27-8; Plac. Abbr., I44a-b; Cal. Close Rolls, I242-1247, 353. The development of trespass from Ir94 on is particularly interesting, as is Bracton's $N$. B., No. II2r : Et Henricus dicit . . . quod blada ita fuerunt asportata et vi et armis et de nocte et hoc pertinet ad Dominum Regem.

In the period before the prerogative courts were regularly established, nearly all the cases brought before the Council were instances of its original jurisdiction. See Valin, Le Duc de Normandie, I06f, ro8. The case in the time of William I before multos ex melioribus totius Anglie baronibus [Bigelow, Placita (I88I) 36] is not the same as that which had just been tried before the bishop of Bayeux. See Adams, Local King's Court in the Reign of William I (IgI4) 23 Yale Law Jourat, 505. See Domesday Book, Iorb; Davis, Regesta, No. 370; Haskins, Norman Instifutions, 88, n. I8, 91 (two cases). Of the cases cited from Bracton's Note Book in note 37 supra as not clearly coram rege cases, the following may well be instances of original jurisdiction: III8-20-25-27-28-29.

"See note 34 supra. 
tling into the hands of a specific body of justices, and that fact is clear from Bracton's statements, the final differentiation is only a question of time. It may be repeated as one anticipation of the later history that the reference of difficult questions to the sapientiores for decision led inevitably to the development of a jurisdiction in error, a superior jurisdiction because that of the Councili3 and therefore over the Bench itself as well as over the itinerant justices. This passed on into the later centuries when the King's Bench is to superficial appearance merely another common law court co-ordinate with the Common Bench, but, though the historical reason was forgotten, the superior jurisdiction was never questioned.

As an institution apparently distinct, or distinguished, from the small curia regis and in its separate capacity trying cases, even clamores or what would later be classed as common pleas, the Exchequer is the oldest of the three common law courts.44 Its action in such a capacity, while in process of differentiation from the Council, is of course what is normally to be expected, since the differentiation was incomplete and even hardly felt to be going on. It can be traced continuously from the reign of Henry $I^{45}$ As the earliest of the institutions so differentiated, it is natural that the period of the process, before it was clearly recognized that a new institution had been formed, should be the longest of any. From early in the twelfth to the end or near the

\footnotetext{
${ }^{43}$ Early cases where the action of the Council is clear are: I Rot. Litt. Claus. 406, 549b; Bracton's N. B., Nos. 67, I166; Cal. Pat. Rolls, 1247-I258, 43I; cf. Bracton's justices a latere regis residentes, qui omnium aliorum corrigere tenentur injurias et errores, f. ro8. Special commissions appointed to correct errors of subordinate courts are interesting, Cal. Pat. Rolls, 1232-1247, 162, 192; 2 Arch. Cambrensis, Series IV, 243. The case in Plac. Abbr. 138, cited in Baldwin, King's Council, 57, as an instance of a writ of error, is the ordinary appeal of false judgment.

4 I Pollock and Maitland, I8g ff.; Poole, Exchequer, 180.

${ }^{45}$ As Mr. Poole says, loc. cit., "there is abundant evidence of common law suits being heard at the Exchequer." I Madox, Exchequer, 209ff. The best known early case is that recorded in a charter printed in 2 Chron. Mon. Abingd., II6, before a rather full small Council in thesauro. Others are: I Madox, Exchequer, 209 a; Plac. Abbr. 84b; Haskins, op. cit. at p. 88, n. 18; cf. Round, Documents in France, xliv; Bigelow, Procedure (I880) 123. It is well known that the Exchequer in Normandy became the general court of common pleas for the duchy, standing in the same relation to the courts of the itinerant justices as the court of Common Pleas in England and passing upon the same class of cases. It possessed a jurisdiction somewhat superior to that of the Common Pleas in England, because the transfer of sovereignty to the crown of France prevented any further development of the curia ducis in Normandy. See L. Delisle, Recueil de Judgments de l'Echiquier de Normandie. It is a natural conjecture that the Exchequer came to occupy this place in the Norman judicial system because no court of Common Pleas was formed there, and that the English Exchequer was well on the way to take the same place when its evolution in this direction was checked by the legisiation of II78.
} 
end of the thirteenth century, ${ }^{46}$ the separation was going on, and during all this time the Exchequer acted sometimes as if it were a separate organ of the Council for a special kind of business, and sometimes as if it were the Council taking advantage of a meeting under a special form to do ordinary Council business. ${ }^{47}$ This action as Council continued, indeed, after it was recognized that there had been a. differentiation, ${ }^{48}$ and in some respects it may be said not to have ceased until the era of modern judicial reforms.

In two particulars the Exchequer court bore into the nineteenth century the marks of its origin in a long process of unconscious differentiation from the Council. One is its independent equity jurisdiction, which we need not here consider in detail, ${ }^{49}$ but which was an inevitable result of its action as Council throughout the twelfth and early thirteenth centuries when equity was not yet distinguished from the common law, or when, it would be more accurate to say, all administration of the law through the royal courts was based upon the fundamental principles which were later recognized as those belonging peculiarly to equity. It should be repeated, however, that this jurisdiction is strong evidence that the Exchequer was regarded as Council, since it exercised a jurisdiction belonging peculiarly to the Council, while the Common Bench was not so recognized.

The second mark of its origin is the treatment of its errors. In

${ }^{4}$ If it were necessary, many instances of the Exchequer acting as a court of law during the thirteenth century could be added to those cited in 2 Madox Exchequer, rof., 26f., 77ff., I18ff. Of special interest are: I Rot. Litt. Claus., 608; Cal. Close Rolls, 1227-1231, 504; Liber de Antiquis Legibuis, Camden Soc., 33; Red Book of the Exchequer, 842. See also cases in which the barons of the Exchequer and the justices of the Bench act together: Cal. Close Rolls, id., 503; id r234-1237, 383; id., I237-1242, 69; Chronicon Petroburgense, Camden Soc., I41; cf. Liber de Antiquis Legibus, 84, and 3 Annales Monastici, 278. The phrase ad scaccarium, which is rather frequent in the judicial documents of the twelfth and thirteenth centuries, is generally interpreted to mean the place at which the court sat and not the court which was sitting and therefore as not necessarily implying the Exchequer court. That this interpretation is correct in many places cannot be questioned. It is clear, however, in some instances that the barons of the Exchequer were the court acting, or formed a part of it, where this phrase is used, and one may suspect that this was true in many instances where the fact is not clearly indicated. See Bracton's $N$. B., No. I095, p. II3; Valin, Duc de Normandie, 278, No. 25; compare two cases in Placita de Quo Warranto, 294. Interesting are two strikingly similar accounts Chron. Mon. de Bello, III, and 2 Chron. Mon. Abingd., 297, and see the story cited in I Madox, Exchequer, 21 $4 x$ from 2 Matth. Par. $50 \%$.

"Baldwin; King's Council, 4Iff: I Madox, Exchequer, 2Igf; 2 id., 26ff; 3 Hovenden, I4I; I Rot. Litt. Claus., 36I, 438b; compare two cases $i d .406 \mathrm{a}$ and b; Cal. Pat. Rolls, I225-I232, 342; Chron. Petrob. 137-8.

4 See the record quoted I Madox, Exchequer, 423 z, and Davies, Baronial Opposition to Edward II (1918) 245 ff.

- Baldwin, King's Council, 223ff.; Adams, Origin of English Equity (1916) 16 CoL. L. Rev. 
the fourteenth century when the court of King's Bench, secure in its jurisdiction in error over the Common Bench, attempted to establish a similar jurisdiction over the Exchequer as a court of common law, the Exchequer successfully resisted. ${ }^{50}$ It based its resistance upon an argument which was historically an incomplete statement of its case, but which was hevertheless historically accurate so far as it went. It declared that it was not a common law court. That was quite true, but it would have been a more complete and effective answer if the whole truth had been stated: that, if the King's Bench corrected the errors of the Common Bench because it was itself an offshoot of the Council at one time indistinguishable from it, while the Common Bench was its creature, then the King's Bench could have no corresponding jurisdiction over the Exchequer court because that was of the same origin and history, a co-ordinate differentiation from the Council and therefore of co-ordinate rank and authority. The argument in the form in which it was put means the same as this and is historically accurate, because, as a court trying cases in the first part of the thirteenth century, the Exchequer was not a court of the new procedure, of the common law procedure, but in reality the Council. It had later gained a share practically in common law jurisdiction by usurpation, by the use of a fiction, the quo minus process, which transformed the case from an ordinary communium placitum into a case falling under its original jurisdiction as financial organ of the Council. That is, common pleas tried in the Exchequer were not technically common pleas or cases at common law. This argument was accepted as good law in the fourteenth century. We must accept it as good history, but we must not overlook the fact that it is practically a demonstration that the court of Common Pleas, as it came to be called, had an institutional origin decidedly different from King's Bench and Exchequer. .

${ }^{50}$ Pike, House of Lords, 293f., Y. B. I4 Edw. III, xxiff; Baldwin, King's Council, 232ff. 